\title{
MENINGKATKAN KEMAMPUAN GURU KELAS DALAM MENCAPAI HASIL BELAJAR MATEMATIKA MELALUI MODEL QUANTUM TEACHING DI SD NEGERI 026408 BINJAI
}

\author{
Mida Mawarni Pasaribu \\ Guru SD Negeri 026408 Binjai \\ mawarni.m@gmail.com
}

\begin{abstract}
This study aims to find out how to do the coaching ability of teachers to improve student learning outcomes Elementary School Mathematics 026408 by using model study of Quantum Teaching. This research is a school action. The approach used in this study is a qualitative approach to the type of action research school. The subjects were 026408 primary school teachers Binjai with number 6 teachers. Data from this study were collected through test results and the results of observation. Results lesson using Quantum Teaching methods result: On average Pre cycle learning outcomes in class was 55.00 so do the implementation of the first cycle with the average value obtained was 65.00, an increase of 10.00 and from the first cycle the second cycle to 65.00 into 90.00 is also an increase of 25.00. Thus in accordance with the criteria established that the model of Quantum Teaching can improve the learning outcomes of teachers on the subject of the rectangle.
\end{abstract}

Keywords: mathematics learning outcomes, rectangle, quantum teaching model

\begin{abstract}
Abstrak. Penelitian ini bertujuan untuk mengetahui bagaimana melakukan pembinaan kemampuan guru dalam meningkatkan hasil belajar Matematika siswa SD Negeri 026408 dengan menggunakan model pembelajaran Quantum Teaching. Penelitian ini adalah penelitian tindakan sekolah. Pendekatan yang digunakan dalam penelitian ini adalah pendekatan kualitatif dengan jenis penelitian tindakan sekolah. Subjek penelitian ini adalah guru SD Negeri 026408 Binjai dengan jumlah 6 orang guru. Data dari penelitian ini dikumpulkan melalui hasil tes dan hasil observasi. Hasil Pelaksanaan Pembelajaran dengan menggunakan metode Quantum Teaching diperoleh hasil : Pada Pra Siklus ratarata hasil pembelajaran dikelas adalah 55,00 sehingga dilakukan pelaksanaan pada siklus I dengan nilai rata-rata diperoleh adalah 65,00, terjadi peningkatan 10,00 dan dari siklus I ke siklus II 65,00 menjadi 90,00 juga terjadi peningkatan sebanyak 25,00. Dengan demikian sesuai dengan kriteria yang ditetapkan bahwa model Quantum Teaching dapat meningkatkan hasil pembelajaran guru pada pokok bahasan persegi panjang.
\end{abstract}

Kata Kunci: hasil belajar matematika, persegi panjang, model quantum teaching

\section{PENDAHULUAN}

Kemajuan teknologi semakin pesat dan banyak memacu dunia pendidikan untuk berpola pikir cepat dan tepat. Pendidikan yang menuntut kepada pola pikir, salah satunya adalah pendidikan matematika sebagai salah satu bidang studi yang diajarkan disetiap jenjang pendidikan. Berdasarkan hasil prestasi matematika siswa di Indonesia masih lebih rendah dibandingkan dengan Malaysia dan Singapura yang jumlah jam pelajarannya setiap tahun lebih sedikit dibandingkan Indonesia.

Maka dari itu guru harus dapat membuat siswa aktif dengan cara mengarahkan pelajaran pada pemahaman konsep dan pemecahan masalah. Dengan begitu peranan guru sangat menentukan keberhasilan guru, untuk itu diharapkan guru dapat memberikan bantuannya pada guru, salah satunya dengan memilih metode atau model pembelajaran yang tepat untuk memahami konsep yang diajarkan. Karena tidak semua metode dapat diterima oleh guru seperti yang dikemukakan Usman (2001) salah satu 
benyebab masalah atau kurangnya pemahaman peserta didik terhadap konsep matematika adalah metode pembelajaran yang digunakan pengajar, misalnya menempatkan guru sebagai pendengar.

Sehubungan dengan proses belajar mengajar matematika, Marpaung (2001:11) juga mengatakan bahwa dalam proses belajar mengajar matematika, harus diciptakan suasana yang tidak menegakan, kalau mungkin suasana harus dibuat menyenangkan. Kesulitan guru pada pembelajaran materi persegi panjang adalah guru sulit membedakan persegi panjang dengan bangun datar lainnya. Selain itu guru belum menguasai operasi pada bentuk aljabar sehingga guru tidak mampu melasaikan soalsoal pada materi persegi panjang. Dari keterangan diatas dapat disimpulkan bahwa kesalahan utama guru dalam mengerjakan soal- soal persegi panjang karena adanya kiesulitan guru yaitu tidak mengenal guru yaitu tidak mengenal sifat-sifat persegi panjang ditinjau dari diagonal, sisi dan sudutnya.

Berkaitan dalam model-model pembelajaran, Sujana (2009) mengatakan bahwa tugas guru adalah memilih berbagai metode yang tepat untuk menciptakan proses belajar mengajar yang baik. Ketepatan kegiatan belajar mengajar. Banyak upaya yang dilakukan guru-guru dalam membuat strategi belajar baru yang lebih memberdayakan guru. Dalam kegiatan mengajar guru harus mampu memilih metode mengajar yang baik. Dengan metode mengajar diharapkan tumbuh berbagai kegiatan belajar guru, sehubungan dengan kegiatan mengajar guru Suryosubroto (1996) menjelaskan bahwa metode adalah cara yang dalam fungsinya merupakan alat untuk mencapai tujuan. Pemilihan dan penetapan metode mengajar mempengaruhi hasil kinerja guru. Hal ini sangat penting dalam proses belajar mengajar, karena semakin tepat penggunaan metode yang digunakan maka semakin baik pula guru dalam menerima dan menyerap pelajaran sehingga akan tercapai hasil belajar yang baik.

Salah satu diantaranya adalah menggunakan pembelajaran quantum teaching. De Porter (2000) menyatakan bahwa quantum teaching merupakan kiat, petunjuk, strategi dan seluruh proses belajar yang dapat mempertajam pemahaman dan daya ingat, serta membuat belajar sebagai proses yang menyenangkan, bermanfaat, penuh dengan kegembiraan, serta antusiasme guru meraih pengetahuan. Quantum teaching juga menciptakan konsep motivasi, langkah-langkah menumbuhkan minat, dan belajar aktif. Jadi, quantum teaching diharapkan dapat membuat guru lebih kreatif, bebas berespresisecara berjanggung jawab. Penggunaan teknik mengajar yang sesuai tentunya memberikan dampak positif terhadap hasil kinerja guru.

\section{METODE}

Penelitian ini dilaksanakan di SD Negeri 026408 Binjai. Subjek penelitian ini adalah guru SD Negeri 026408 Binjai, dengan jumlah 6 orang guru kelas. Objek dalam penelitian ini adalah pembelajaran matematika dengan menerapkan metode quantum teaching pada materi persegi panjang di SD Negeri 026408 Binjai. Jenis penelitian ini merupakan penelitian deskriptif yang bertujuan menggambarkan keefektifan pengajaran dengan menerapkan quantum teaching pada materi persegi panjang.

Penelitian ini bertujuan untuk mengetahui keefektifan pengajaran. Rancangan pelitian ini dapat digambarkan sebagai berikut: Prosedur dan metode penelitian yang digunakan dalam penelitian ini adalah penelitian tindakan kelas (action research) yang terdiri dari dua siklus dan tiap siklus dilaksanakan sesuai dengan rencana dan perubahan yang terjadi seperti apa yang telah direncanakan sebelumnya. Setiap siklus 
direncanakan selama 1,5 bulan kalender. Penelitian ini berlangsung sesuai dengan prinsip penelitian tindakan kelas.

\section{a) Perencanaan}

Kegiatan yang dilakukan pada tahap perencanaan adalah sebagai berikut:

1) Menganalisa dan mengamati (observasi awal) di SD mengenai proses pembelajaran tentang pokok bahasan persegi panjang.

2) Menganalisa dan mengkaji buku teks SD mengenai materi dan melalui pendekatan quantum teaching.

3) Membuat test diagnostik sebagai instrumen awal untuk mengetahui kemampuan awal guru.

4) Mengidentifikasi masalah-masalah dan permasalahan yang akan dipecahkan terutama berdasarkan hasil test diagnostik.

5) Menyiapkan dan merancang bahan/materi yang akan digunakan selama siklus berlangsung dengan merujuk pada buku teks yang digunakan dan atau buku teks lain yang relevan.

6) Mempersiapkan tes perkembnagan/kemajuan (progress test) kemampuan dan tes akhir setiap siklus.

7) Mempersiapkan dan membuat media dan alat bantu pembelajaran atau bahan pembelajaran yang diperlukan dalam pelaksanaan skenario yang telah ditetapkan.

8) Membuat dan menyiapkan lembaran observasi yang digunakan untuk mengetahui reaksi guru dan suasana dan kondisi kelas secara keseluruhan dan perkembangannya dalam penerapan pada pokok bahasan persegi panjang.

9) Membuat lembaran observasi untuk mengetahui tingkat keaktifan guru dalam pembelajaran dengan menggunakan pendekatan quantum teaching dengan pokok bahasan Persegi panjang.

10) Membuat dan merancang angket tentang persepsi guru terhadap materi/bahan yang disajikan, tingkat kesukarannya, waktu yang dialokasikan, dan pelaksanaan belajar guru melalui pendekatan quantum teaching.

11) Membuat dan merancang angket tentang persepsi guru terhadap belajar guru melalui quantum teaching pada pokok bahasan persegi panjang, setelah berakhir siklus II.

12) Merancang dan mendisain pola pelaksanaan skenario pembelajaran dengan pendekatan quantuim teaching pada pokok bahasan persegi panjang.

b) Implementasi Tindakan

Dalam tahap implementasi, model atau metode atau scenario pembelajaran yang telah disusun dan dirancang/dilaksanakan di kelas. Tentu saja, materi yang disajikan dalam tiap siklus diambil dan diadopsi dari buku teks matematika SD yang digunakan dibeberapa sekolah dasar Binjai dan mengadopsi materi dari buku SD lain yang relevan. Dua siklus akan diimplementasikan dalam tulisan ini dan tiap siklus akan berlangsung kurang lebih 1,5 bulan.

c) Observasi dan Interprestasi

Observasi dilaksanakan ketika pelaksanaan penelitian tindakan sedang berlangsung dengan menggunakan lembar observasi yang telah dirancang sebelumnya. Pengamatan dilakukan terhadap semua kegiatan proses dan suasana pembelajaran melalui melalui pendekatan quantum teaching. Angket juga akan diberikan untuk mendapatkan data/informasi tentang pendapat guru mengenai 
pendektan quantum teaching. Kemudian menganalisa hasil evaluasi dan refleksi hasil temuan guna sebagai acuan pada pelaksanaan tindakan berikutnya.

\section{d) Analisis dan Refleksi}

Hasil yang telah diperoleh berupa data tes kemampuan, angket, dan lembaran observasi serta wawancara langsung dikumpulkan dan dianalisis. Dari tahap ini guru (peneliti) dapat merefleksikan data yang ada apakah kegiatan ini tindakan dapat meningkatkan apa yang menjadi tujuan penelitian ini. Dari hasil yang diperoleh dapat disimpulkan apakah pembelajaran matematika dengan menggunakan pendekatan quantum teaching pada pokok bahasan persegi panjang dapat meningkatkan motivasi, minat, efektifitas, dan efisiensi serta yang paling penting adalah peningkatan kemampuan penguasaan matematika guru.

Analisa data tentang efektifitas pembelajaran matematika dengan penerapan model pembelajaran quantum teaching dilakukan dengan analisis deskriptif. Untuk menentukan persentase daya serap guru secara individual digunakan rumus sebagi berikut:

$$
\mathrm{X}=\frac{S_{s}}{S_{\text {maks }}} \times 100 \%
$$

Keterangan:

$\mathrm{X} \quad$ : Daya serap perorangan (\%)

$\mathrm{S}_{\mathrm{S}} \quad$ : Skor yang diperoleh guru

$\mathrm{S}_{\text {maks }} \quad$ : Skor maksimal guru

Dengan kriteria: $0 \% \leq X<65 \%$

$$
65 \% \leq X \leq 100 \%
$$

tidak tuntas belajar tuntas belajar

Secara individu, guru dikatakan telah tuntas belajar apabila $X \geq 65 \%$

Dan untuk menentukan daya serap klasikal suatu kelas digunakan rumus:

$\mathrm{Y}=\frac{M}{N} \times 100 \%$

Keterangan:

Y : Daya serap klasikal (\%)

M : Banyaknya guru dengan daya serap perorangan sama atau lebih besar dari $65 \%$

$\mathrm{N}$ : Jumlah seluruh guru

Selanjutnya suatu kelas dikatakan telah tuntas jika daya serap klasikal kelas tersebut sama atau lebih besar dari $85 \%$.

\section{HASIL DAN PEMBAHASAN}

\section{Hasil}

Berdasarkan analisis data tentang jawaban guru pada soal yang diberikan melalui tes hasil kinerja guru. Dari data yang diperoleh dihitung persentase banyaknya guru yang tuntas belajar, tingkat ketercapaian Tujuan Pembelajaran dan hasil observasi kegiatan pembelajaran. Hal ini bertujuan untuk mengetahui efektivitas pembelajaran tersebut. Pada penelitian ini, pada saat pembelajaran dengan penerapan pembelajaran quantum teaching pada materi persegi panjang berlangsung, pengamat yang telah ditentukan mengisi lembar observasi. Setelah seluruh materi diajarkan, barulah diberikan tes hasil kinerja guru, dapat diketahui efektivitas pembelajaran dengan menggunakan pengajaran quantum teaching pada materi persegi panjang. 


\section{Pra Siklus}

Tahap Perencanaan

Pada tahap ini peneliti mempersiapkan perangkat Pelaksanaan Pembelajaran di kelas yang terdiri dari rencana, dan alat-alat Pelaksanaan Pembelajaran Pra Siklus yang mendukung. Selain itu juga dipersiapkan lembar observasi kinerja guru.

\section{Tahap Kegiatan dan Pelaksanaan}

Pelaksanaan kegiatan pembelajaran di kelas untuk Pra Siklus dilaksanakan di SD Negeri 026408 Binjai. Adapun proses pelaksanaan pembelajaran di kelas mengacu pada rencana Pelaksanaan Pembelajaran di kelas yang telah dipersiapkan. Pengamatan (observasi) dilaksanakan bersama dengan pelaksanaan proses belajar mengajar di sekolah. Adapun data hasil penelitian Pra Siklus adalah seperti pada table berikut:

Tabel 1. Nilai Hasil Pembelajaran Matematika di Kelas Pada Pra Siklus

\begin{tabular}{ccccc}
\hline No & Kode Guru & Nilai & Tuntas & Tidak Tuntas \\
\hline 1 & RA & 60 & - & $\sqrt{ }$ \\
\hline 2 & SG & 50 & - & $\sqrt{ }$ \\
\hline 3 & RJ & 55 & - & $\sqrt{ }$ \\
\hline 4 & EAD & 50 & - & $\sqrt{ }$ \\
\hline 5 & AI & 60 & - & $\sqrt{ }$ \\
\hline 6 & TUM & 55 & - & $\sqrt{ }$ \\
\hline & Jumlah Nilai & 330 & - & - \\
\hline & Nilai Maksimum & 600 & - & - \\
\hline & Nilai Rata-Rata & 55,00 & - & - \\
\hline
\end{tabular}

\section{Revisi Rancangan}

Pelaksanaan kegiatan pelaksanaan pembelajaran di kelas pada pra siklus ini terdapat kekurangan sehingga perlu adanya revisi untuk dilakukan pada siklus berikutnya.

1. Kepala sekolah perlu lebih terampil dalam memotivasi guru dan lebih jelas dalam menyampaikan tujuan pelaksanaan pembelajaran di kelas. Dimana guru diajak untuk terlibat langsung dalam setiap kegiatan yang akan dilakukan.

2. Kepala sekolah perlu mendistribusikan waktu secara baik dengan menambahkan informasi-informasi yang dirasa perlu dan memberi catatan.

3. Kepala sekolah harus lebih terampil dan bersemangat dalam memotivasi guru sehingga mutu pembelajaran lebih meningkat.

\section{Siklus I}

Tahap perencanaan

Pada tahap ini peneliti mempersiapkan perangkat Pelaksanaan Pembelajaran di kelas yang terdiri dari Rencana Pelaksanaan Pembelajaran di kelas, angket isian siklus I dan alat-alat Pelaksanaan Pembelajaran di kelas lain yang mendukung.

\section{Tahap Kegiatan dan Pelaksanaan}

Adapun proses pelaksanaan pembelajaran di kelas mengacu pada rencana pelaksanaan pembelajaran di kelas dengan memperhatikan revisi pada pra siklus, sehingga kesalahan atau kekurangan pada pra siklus tidak terulang lagi pada siklus I. 
Tabel 2. Nilai Hasil Pembelajaran Matematika di Kelas Pada Siklus I

\begin{tabular}{ccccc}
\hline No & Kode Guru & Nilai & Tuntas & Tidak Tuntas \\
\hline 1 & RA & 75 & $\sqrt{ }$ & - \\
\hline 2 & SG & 60 & - & $\sqrt{ }$ \\
\hline 3 & RJ & 60 & - & $\sqrt{ }$ \\
\hline 4 & EAD & 60 & - & $\sqrt{ }$ \\
\hline 5 & AI & 75 & $\sqrt{ }$ & - \\
\hline 6 & TUM & 60 & - & $\sqrt{ }$ \\
\hline & Jumlah Nilai & 390 & - & - \\
\hline & Nilai Maksimum & 600 & - & - \\
\hline & Nilai Rata-Rata & 65,00 & - & - \\
\hline
\end{tabular}

Refleksi

Dalam pelaksanaan pembelajaran dikelas diperoleh informasi dari hasil pengamatan sebagai berikut:

1) Memotivasi guru

2) Membimbing guru dalam kegiatan belajar mengajar.

3) Pengelolaan waktu

\section{Revisi Pelaksanaan}

Pelaksanaan Pelaksanaan Pembelajaran di kelas pada siklus I ini masih terdapat kekurangan-kekurangan. Maka perlu adanya revisi untuk dilaksanakan pada siklus II antara lain:

(1) Dalam memberikan pelaksanaan pembelajaran di kelas hendaknya dapat membuat peserta (guru) termotivasi dalam kegiatan pembelajaran di kelas.

(2) Harus lebih dekat dengan peserta (guru) sehingga tidak ada perasaan takut/malu dalam diri terutama dalam bertanya tentang masalah yang dihadapi dalam kegiatan belajar mengajar.

(3) Harus lebih sabar dalam melakukan pelaksanaan pembelajaran di kelas peserta (guru) terutama dalam merumuskan kesimpulan/menemukan konsep.

(4) Harus mendistribusikan waktu secara baik sehingga kegiatan pelaksanaan pembelajaran di kelas dapat berjalan efektif sesuai dengan yang diharapkan.

\section{Siklus II}

Tahap Perencanaan

Pada tahap ini peneliti mempersiapkan perangkat pelaksanaan pembelajaran di kelas yang terdiri dari rencana pelaksanaan pembelajaran di kelas, angket isian siklus dan alat alat pelaksanaan pembelajaran di kelas lainnya yang mendukung.

Tahap kegiatan dan pengamatan

Adapun proses Pelaksanaan Pembelajaran di kelas mengacu pada rencana pelaksanaan pembelajaran di kelas dengan memperhatikan revisi pada siklus I, sehingga kesalahan atau kekurangan pada siklus I tidak terulang lagi pada siklus II. Pengamatan (obsevasi) dilaksanakan bersamaan dengan proses pembelajaran di sekolah. Adapun data hasil penelitian pada siklus II adalah sebagai berikut: 
Tabel 3. Nilai Hasil Pembelajaran Matematika di Kelas Pada Siklus II

\begin{tabular}{ccccc}
\hline No & Kode Guru & Nilai & Tuntas & Tidak Tuntas \\
\hline 1 & RA & 95 & $\sqrt{ }$ & - \\
\hline 2 & SG & 85 & $\sqrt{ }$ & - \\
\hline 3 & RJ & 85 & $\sqrt{ }$ & - \\
\hline 4 & EAD & 90 & $\sqrt{ }$ & - \\
\hline 5 & AI & 95 & $\sqrt{ }$ & - \\
\hline 6 & TUM & 90 & $\sqrt{ }$ & - \\
\hline & Jumlah Nilai & 540 & - & - \\
\hline & Nilai Maksimum & 100 & - & - \\
\hline & Nilai Rata-Rata & 90,00 & - & - \\
\hline
\end{tabular}

Berdasarkan tabel diatas diperoleh nilai rata-rata tes sebesar 90,00 dan dari 6 orang guru secara keseluruhan sudah mencapai ketuntasan dalam meningkatkan peran dan fungsinya. Maka secara kelompok ketuntasan telah mencapai 100\% (termasuk kategori tuntas). Hasil pada siklus II ini mengalami peningkatan lebih baik dari siklus I.

\section{Pembahasan} bahwa

Berdasarkan hasil perolehan data dan hasil analisis tersebut dapat disimpulkan

a. Terjadi peningkatan proses kegiatan belajar mengajar mata pelajaran matematika di kelas dengan nilai rata-rata sebesar 55,00 menjadi 90,00 ada kenaikan sebesar 35,00 .

b. Dari sebelum Pelaksanaan Pembelajaran di kelas (pra siklus) dan setelah Pelaksanaan Pembelajaran di kelas oleh kepala sekolah sampai dengan siklus I dengan nilai rata-rata adalah 55,00 menjadi 65,00, terjadi peningkatan 10,00 dan dari siklus I ke siklus II 65,00 menjadi 90,00 juga terjadi peningkatan sebanyak 25,00 .

c. Rata-rata peningkatan proses kegiatan belajar mengajar mata pelajaran matematika di kelas sebelum diberi Pelaksanaan Pembelajaran di kelas dengan nilai rata-rata naik dari 55,00 menjadi 90,00.

Disamping itu juga berdasarkan hasil observasi yang dilakukan oleh observer, diperoleh data:

Tabel 5. Deskripsi Hasil Observasi

\begin{tabular}{ccccc}
\hline \multicolumn{3}{c}{ Hasil Pertemuan } & \multirow{2}{*}{ Rata-rata } & \multirow{2}{*}{ Kategori } \\
\cline { 1 - 3 } Pertemuan I & Pertemuan II & Pertemuan III & & \\
\hline 3,28 & 3,42 & 3,42 & 3,37 & Baik \\
\hline
\end{tabular}

Dari tabel di atas diketahui bahwa rata-rata dari pertemuan I, II dan III adalah 3,37. Berdasarkan kriteria penilaian observasi, maka pembelajaran dengan menggunakan model quantum teaching termasuk dalam kategori baik. Dari penelitian terhadap 6 orang guru yang mengikuti pembelajaran dengan menggunakan model pembelajaran quantum teaching pada materi persegi panjang diperoleh:

1. Sesuai dengan kriteria ketuntasan belajar pada kelas yang diajarkan dengan menggunakan model pembelajaran quantum teaching tercapai. Dari data tes hasil belajar guru menunjukkan, 6 guru atau 100\% yang telah tuntas belajar. 
2. Hasil observasi penelitian yang dilakukan observer menunjukkan bahwa pelaksanaan belajar dengan menerapkan model pembelajaran quantum teaching pada materi persegi panjang berjalan dengan baik. Dimana diketahui bahwa ratarata dari pertemuan I sampai dengan pertemuan III adalah 3,37. Berdasarkan kriteria penilaian hasil observasi menunjukkan bahwa pelaksanaan pembelajaran yang dilakukan berada pada rentang nilai 2 dan 3 . Hal ini berarti pembelajaran yang dilakukan termasuk dalam kategori baik.

3. Dengan dipenuhinya ketiga kriteria tersebut sebagaimana yang telah ditentukan maka dapat disimpulkan bahwa pembelajaran dengan menerapkan quantum teaching pada materi persegi panjang efektif digunakan.

\section{KESIMPULAN DAN SARAN \\ Kesimpulan}

Berdasarkan hasil penelitian, ditemukan bahwa pembelajaran dengan menggunakan model pembelajaran quantum teaching dilihat dari syarat keefektifen yaitu:

1. Ketuntasan belajar guru secara klasikal telah tercapai, dan pelaksanaan quantum teaching berjalan dengan baik maka pembelajaran matematika dengan menerapkan quantum teaching efektif dilakukan pada materi persegi panjang di SD Negeri 026408 Binjai.

2. Hasil Pelaksanaan Pembelajaran dengan menggunakan metode quantum teaching diperoleh hasil: Pada pra siklus rata-rata hasil pembelajaran dikelas adalah 55,00 sehingga dilakukan pelaksanaan pada siklus I dengan nilai rata-rata diperoleh adalah 65,00, terjadi peningkatan 10,00 dan dari siklus I ke siklus II 65,00 menjadi 90,00 juga terjadi peningkatan sebanyak 25,00 .

3. Dari Nilai tersebut diperoleh kesimpulan bahwa melalui model quantum teaching dalam meningkatkan kemampuan guru kelas mencapai hasil belajar matematika pada materi persegi panjang di SD Negeri 026408 Binjai didapatkan hasil yang sangat baik.

\section{Saran}

Berdasarkan penelitian ini, peneliti mengemukakan saran-saran sebagai berikut:

1. Guru matematika hendaknya dapat menerapkan model pembelajaran quantum teaching ini pada materi persegi panjang dan materi matematika lainnya dalam memperbaiki hasil belajar matematika.

2. Bagi pihak sekolah pentingnya memperhatikan dan mempelajari model-model pembelajaran lain yang sesuai digunakan oleh guru dalam proses belajar mengajar.

3. Kepada peneliti selanjutnya yang berminat, agar dapat meneliti di sekolah pada materi yang berbeda agar dapat dijadikan sebagai studi perbandingan guru untuk meningkatkan kualitas pendidikan khususnya mata pelajaran matematika.

4. Untuk menerapkan pembelajaran quantum teaching hendaknya diperhatikan lagi materi yang akan diajarkan, karena tidak semua materi dapat diajarkan dengan menerapkan pembelajaran quantum teaching ini.

\section{DAFTAR PUSTAKA}

De Poerter, B. dkk. 2000. Quantum Teaching. Bandung: Penerbit Kaifa.

Marpaung,Y. 2000. Implementasi Pendidikan Matematika Realistik di Indonesia.

Seminar Sehari. Departemen Agama Propinsi Sumatera Utara. 
Vol. 3, No. 1, Oktober 2017

Sujana, N. 2009. Penilaian Proses Hasil Belajar Mengajar. Bandung: Penerbit Remaja Rosdakarya.

Suryosubroto. 1996. Proses Belajar Mengajar di Sekolah. Jakarta: Rineka Cipta.

Usman, H. B. 2001. Meningkatkan Pemahaman guru Tentang Konsep Limit Melalui Pemebelajaran Kooperatif. Jurnal Ilmu Pendidikan. Universitas Negeri Malang. Malang. 